\title{
Clinical features and outcome of acute hepatitis B in pregnancy
}

\author{
Yong-Tao Han ${ }^{1 \dagger}$, Chao Sun ${ }^{2 \dagger}$, Cai-Xia Liư ${ }^{2 \dagger}$, Shuang-Shuang Xie², Di Xiao², Li Liu², Jin-Hong Yu², Wen-Wen Li \\ and Qiang Li ${ }^{2^{*}}$
}

\begin{abstract}
Background: The impact of pregnancy on the clinical course of acute hepatitis B (AHB) is still largely unclear, mainly because most studies have not included matched controls. This study was conducted to investigate the clinical features and outcome of AHB in pregnancy using matched controls.

Methods: Consecutive AHB inpatients who were admitted to Jinan Infectious Disease Hospital, Jinan, between January 2006 and December 2010 were evaluated and followed. Demographic data, clinical manifestations, and results of laboratory tests were compared between pregnant patients and age and sex matched non-pregnant patients at admission, discharge, and final follow-up.

Results: A total of 618 AHB inpatients were identified during the study period. 22 pregnant patients and 87 age and sex matched non-pregnant patients were enrolled in this study. Prodromal fever was less common $(0 \%$ vs. 20.7\%, $P=0.02$ ), serum alanine aminotransferase levels were significantly lower, and $\mathrm{HBsAg}>250 \mathrm{IU} / \mathrm{mL}$ rate and serum bilirubin levels were significantly higher in pregnant patients than in non-pregnant patients. After a mean (range) of 7(5.2-8.3) months follow-up, 18.2\% pregnant patients and 4.6\% non-pregnant patients were still HBsAg positive $(P=0.03)$. For pregnant patients, the relative risk ( $95 \%$ confidence interval) of HBsAg positive at the end of follow-up was 4.6 (1.1-20.2). The median (95\% confidence interval) days of HBsAg seroclearance form disease onset in pregnant and non-pregnant patients were 145.0 (110.5-179.5) and 80.0 (62.6-97.4), respectively.
\end{abstract}

Conclusions: The HBsAg loss and seroconversion were delayed and lower in pregnant patients. Pregnancy might be a possible risk of chronicity following acute HBV infection.

Keywords: Acute hepatitis B, Pregnancy, Clinical features, Outcome, Hepatitis B surface antigen, Chronicity

\section{Background}

It is well-known that acute hepatitis B virus (HBV) infection in adults is usually self-limiting, of which only 5\%-10\% develop to chronic HBV infection, and about $1 \%$ progress to acute liver failure [1]. However, in certain special populations, such as pregnant women, the clinical course of acute hepatitis B (AHB) is still largely unclear. Although a few studies have investigated the impact of pregnancy on AHB, few of them included matched controls [2-8]. Age, sex, and host immunity status are important factors influencing the clinical manifestation and outcome of acute HBV infection [9]. Clinical features and

\footnotetext{
* Correspondence: doctorliqiang@gmail.com

${ }^{\dagger}$ Equal contributors

${ }^{2}$ Division of Liver Disease, Jinan Infectious Disease Hospital, Shandong

University, Jinan, China

Full list of author information is available at the end of the article
}

HBV serological outcome in pregnant AHB patients, such as hepatitis B surface antigen (HBsAg) loss and seroconversion, have not fully been elucidated.

The clinical presentation and natural history of HBV infection is mediated through complex interactions between the virus and the host immune response [10]. In acute HBV infection, both host innate immunity and HBV specific adaptive immunity play important roles in viral clearance $[10,11]$. Impaired immunity due to various causes may influence the course of AHB [9,12-14]. During pregnancy, the maternal immune system is altered to tolerate the genetically different fetus, and hormonal factors may also play a significant role in altering immune regulation or viral replication [15]. An early study by Mohite et al. reported that the $\mathrm{T}$ cell response to $\mathrm{HBsAg}$ was weaker in pregnant women than in adults 
males and non-pregnant females [16]. So, immunological response to acute $\mathrm{HBV}$ infection, and consequently the clinical course of AHB in pregnant women may differ from those in the general population [16].

The aim of this study was to investigate the clinical features and outcome of AHB in pregnancy.

\section{Methods}

\section{Study design and population}

The present study was performed in the Jinan Infectious Disease Hospital, the only hospital in the Jinan area which is in charge of the diagnosis and treatment of the 35 notifiable infectious diseases of China. This study is part of a hospital-based prospective investigation to study the natural history of acute HBV infection that was conducted in the hospital,in which all inpatients with confirmed AHB between January 2006 and December 2010 were included and followed. The study was approved by the hospital ethics committee, and written informed consent for participation was obtained from each study participant or their next of kins.

The diagnosis of AHB was based on discrete onset of symptoms (such as: fever, loss of appetite, fatigue, and dark urine), jaundice, elevated serum alanine aminotransferase (ALT) or aspartate aminotransferase (AST) levels, detection of high-titer IgM antibody to hepatitis core antigen (anti-HBc), and compatible clinical history $[17,18]$.

Patients with a history or other evidence of liver disease other than $\mathrm{AHB}$, or with alcohol consumption of more than $20 \mathrm{~g} /$ day for more than five years were excluded. All patients were to be followed for at least 6 months. In general, follow-up schedule was 1 month, 3 months, and 6 months after discharge.

In this study, the clinical manifestation, biochemical and virological parameters, and outcome of pregnant AHB patients were compared with those of sex and age matched non-pregnant AHB patients.

\section{Study variables}

The variables analyzed in this study included demographic data, prodromal signs and symptoms, complications, serum biochemical parameters, HBV serological marker, HBV DNA levels at admission, discharge and final follow-up. Days from disease onset to patient's hospital admission, duration of hospitalization and follow-up were also analyzed.

Upon entry to the hospital, all patients were interviewed by trained physicians. The details of information collection and laboratory measurements were previously described $[19,20]$. The transmission routes and risk factors of HBV infection were recorded using a structured questionnaire. In general, biochemical parameters, HBV serological markers, and HBV DNA levels, were measured at least once at admission, before discharge, and at each visit during follow-up. A form designed for this investigation was used to record the information collected at every visit.

For patients with jaundice, prodromal manifestations were defined as signs or symptoms occurring in the 1-10 days before onset of icterus (prodromal period). For patients without jaundice, prodromal manifestations were defined as signs or symptoms occurring in the 1-10 days before diagnosis of hepatitis or the hospital admission.

Prodromal signs and symptoms analyzed in this study included fever, loss of appetite, fatigue. Prodromal fever were defined in 2 different ways: patients reporting a measured fever $\geq 37.5^{\circ} \mathrm{C}$ during prodromal period; any fever (measured or subjective) during prodromal period $[21,22]$. Jaundice referred to measured serum total bilirubin $>25 \mu \mathrm{mol} / \mathrm{L}$ at admission. HE was diagnosed and classified as previously described [23]. The presence of ascites was evaluated using B ultrasonography.

Clinical outcome included occurrence of fulminant hepatitis, clinical recovery (defined as relief of signs and symptoms and normalization of ALT levels), and mortality. HBV virological and serological outcome included undetectable HBV DNA, HBsAg loss, HBsAg seroconversion (i.e. loss of HBsAg and appearance of anti-HBsAg antibodies), hepatitis $\mathrm{B}$ e antigen ( $\mathrm{HBeAg}$ ) seroconversion (i.e. loss of HBeAg and appearance of anti-HBeAg antibodies). Chronic HBV infection was defined as persistent of HBsAg in serum with or without detectable serum HBV DNA after disease onset of more than 6 months [24]. AHB with evidence of coagulation abnormality (INR $\geq$ $1.5)$ and encephalopathy was diagnosed as acute fulminant hepatitis [23].

\section{Statistical analysis}

Clinical parameters were evaluated using the chi-squared test for discrete variables and the $t$ test or Mann-Whitney $\mathrm{U}$ test for continuous variables. A Kaplan-Meier estimate was performed to compare the fraction of patients remain HBsAg positive and days of HBsAg seroclearance after disease onset, and $\mathrm{p}$ values were calculated using log-rank test. For all tests, a $P$ value of less than 0.05 was considered significant. All data analyses were performed using SPSS v. 16.0 (SPSS Inc., Chicago, IL, USA).

\section{Results}

Among a total of 618 inpatients diagnosed with AHB during the study period, 22 pregnant patients were enrolled into the pregnant group. The mean \pm SD and median (min-max) age of the AHB in pregnant patients was $22.7 \pm 1.9$ years and $22(21-28)$ years, respectively. 87 female non-pregnant patients between 21 and 28 years of age were enrolled in the control group. 


\section{Demographic characteristics of AHB in pregnancy}

The demographic characteristics of the two groups are summarized in Table 1. Most pregnant AHB patients were from rural areas of Shandong Province (90.9\%). The mean length from onset of signs and symptoms to hospital admission was similar between the two groups. Of the 22 pregnant AHB patients, 8 were in the first trimester, 8 were in the second trimester, and 6 were in the third trimester of pregnancy. The mean length (minmax) of pregnancy was 17.3 (7-31) weeks. $72.5 \%$ of the patients ever exposed to at least one potential risk factor of acute HBV infection. No pregnant patients had gestational diabetes mellitus.

Clinical and biochemical characteristics of AHB in pregnancy As shown in Table 2, fever was less frequent, and jaundice was more frequent in pregnant patients than in non-pregnant patients.

The biochemical data of pregnant and non-pregnant AHB patients at admission, discharge, and final follow-up are summarized in Table 3. At admission, the median ALT levels of pregnant patients were significantly lower than that of non-pregnant patients. The median total serum bilirubin level was higher in pregnant patients than

Table 1 Demographics and the risk factors exposed within 6 months before onset of AHB: comparison of pregnant and non-pregnant patients

\begin{tabular}{|c|c|c|c|}
\hline Variables & $\begin{array}{l}\text { Non-pregnant } A H B \\
\text { patients } \mathrm{N}=87\end{array}$ & $\begin{array}{l}\text { Pregnant } A H B \\
\text { patients } N=22\end{array}$ & $P$ \\
\hline Age (years) & $23.3 \pm 2.6$ & $22.7 \pm 1.9$ & 0.18 \\
\hline Residence & & & 0.001 \\
\hline Urban & $42(48.3 \%)$ & $2(9.1 \%)$ & \\
\hline Rural & $45(51.7 \%)$ & $20(90.9 \%)$ & \\
\hline $\begin{array}{l}\text { Days from disease } \\
\text { onset to hospital } \\
\text { admission }\end{array}$ & $10.9 \pm 7.5$ & $10.6 \pm 4.1$ & 0.78 \\
\hline $\begin{array}{l}\text { Days of stay in } \\
\text { hospital }\end{array}$ & $28.7 \pm 10.3$ & $24.7 \pm 7.4$ & 0.09 \\
\hline Weeks of pregnancy & NA & $17.3 \pm 8.7$ & NA \\
\hline Potential risk factors & & & 0.17 \\
\hline $\begin{array}{l}\text { Spouse with HBV } \\
\text { infection }\end{array}$ & $8(9.2 \%)$ & $6(27.3 \%)$ & \\
\hline $\begin{array}{l}\text { Other family members } \\
\text { with HBV infection }\end{array}$ & $3(3.4 \%)$ & $1(4.5 \%)$ & \\
\hline Risk sex behavior & $32(36.8 \%)$ & $3(13.6 \%)$ & \\
\hline $\begin{array}{l}\text { Invasive medical } \\
\text { procedure }\end{array}$ & $12(13.8 \%)$ & $4(18.2 \%)$ & \\
\hline Body care & $8(9.2 \%)$ & $2(9.1 \%)$ & \\
\hline Unknown & $24(27.6 \%)$ & $6(27.3 \%)$ & \\
\hline More than one factor & $35(55.6 \%)$ & $7(45.7 \%)$ & 0.40 \\
\hline
\end{tabular}

NOTE. Data are expressed as mean \pm SD or $n$ (\%) of patients; AHB, acute hepatitis $B$.
Table 2 Symptoms,signs, and complications of pregnant and non-pregnant AHB patients

\begin{tabular}{llll}
\hline Variables & $\begin{array}{l}\text { Non-pregnant AHB } \\
\text { patients } \mathbf{N = 8 7}(\%)\end{array}$ & $\begin{array}{l}\text { Pregnant AHB } \\
\text { patients } \mathbf{N}=\mathbf{2 2}(\%)\end{array}$ & $\boldsymbol{P}$ \\
\hline Fever & $18(20.7)$ & $0(0)$ & 0.02 \\
Fatigue & $65(74.7)$ & $15(68.2)$ & 0.54 \\
Loss of appetite & $70(80.5)$ & $14(63.6)$ & 0.08 \\
Jaundice & $56(62.2)$ & $19(95.4)$ & 0.003 \\
Ascites & $1(1.15)$ & $0(0)$ & 0.61 \\
Encephalopathy & $1(1.15)$ & $0(0)$ & 0.61 \\
\hline
\end{tabular}

NOTE. AHB, acute hepatitis $B$.

in non-pregnant patients. The median serum albumin and gamma-glutmyltransferase (GGT) levels were both significantly lower in pregnant patients than in non-pregnant patients $(P<0.001)$.

After a mean (min-max) of 27.8 (5-69) day's supportive treatment, clinical manifestations and biochemical data of all patients were significantly improved.

After a mean (min-max) of 7 (5.2-8.3) months followup, ALT and bilirubin normalization rate were similar between the two groups. However, the median ALT, serum albumin and GGT levels were still significantly lower in pregnant patients than in non-pregnant patients.

\section{HBV virological and serological outcome of $A H B$ in pregnancy}

The HBV virological and serological biochemical data of pregnant and non-pregnant AHB patients at admission, discharge, and final follow-up are summarized in Table 4. At admission, the median HBV DNA level was similar between the two groups $(P=0.69)$, and the HBV DNA > 1000 copies/mL rate was also similar between the two groups. The HBsAg positive $(>0.05 \mathrm{IU} / \mathrm{mL})$ rate was similar between the two groups. The HBsAg $>250 \mathrm{IU} / \mathrm{mL}$ rate and $\mathrm{HBeAg}$ positive rate were significantly higher in pregnant than in non-pregnant patients.

At discharge, the HBsAg positive rate was significantly higher in pregnant patients than in non-pregnant patients, whereas virological and other serological parameters were similar between the two groups.

At final follow-up, the HBsAg positive rate was significantly higher in pregnant patients than in non-pregnant patients. $18.2 \%$ pregnant patients and $4.6 \%$ non-pregnant patients developed chronic HBV infection. For pregnant patients, the relative risk (95\% confidence interval) of $\mathrm{HBsAg}$ positive at the end of follow-up was 4.6 (1.1-20.2). The Kaplan-Meier estimates showed the median (95\% confidence interval) days of HBsAg seroclearance form disease onset in pregnant and non-pregnant patients were 145.0 (110.5-179.5) and 80.0 (62.6-97.4), respectively (Figure 1). 
Table 3 Biochemical data in pregnant and non-pregnant AHB patients at admission, discharge and final follow-up

\begin{tabular}{|c|c|c|c|}
\hline Variables & Non-pregnant AHB patients $\mathrm{N}=87$ & Pregnant AHB patients $\mathrm{N}=22$ & $P$ \\
\hline \multicolumn{4}{|l|}{ At admission } \\
\hline Days from disease onset to examination & $11.8 \pm 7.3$ & $11.3 \pm 4.1$ & 0.70 \\
\hline$A L T(I U / L)$ & $1237(274-3615)$ & $1025(285-1797)$ & 0.039 \\
\hline ALT > $1600 \mathrm{IU} / \mathrm{L}$ & $27(31.0 \%)$ & $1(4.5 \%)$ & 0.01 \\
\hline Bilirubin $(\mu \mathrm{mol} / \mathrm{L})$ & $66.4(8.2-549.7)$ & $140(29.6-289.1)$ & 0.005 \\
\hline Bilirubin $>25 \mu \mathrm{mol} / \mathrm{L}$ & $69(79.3 \%)$ & $22(100 \%)$ & 0.02 \\
\hline Albumin(g/L) & $39.0(28-66)$ & $33.0(23.0-42.3)$ & $<0.001$ \\
\hline Albumin $<35 \mathrm{~g} / \mathrm{L}$ & $12(13.8 \%)$ & $14(63.6 \%)$ & $<0.001$ \\
\hline GGT(IU/L) & $95(22-425)$ & $32.5(21-159)$ & $<0.001$ \\
\hline $\mathrm{GGT}>64 \mathrm{IU} / \mathrm{L}$ & $68(78.1 \%)$ & $4(18.2 \%)$ & $<0.001$ \\
\hline \multicolumn{4}{|l|}{ At discharge } \\
\hline Days from disease onset to examination & $38.6 \pm 11.9$ & $34.2 \pm 7.1$ & 0.11 \\
\hline $\mathrm{ALT}(\mathrm{IU} / \mathrm{L})$ & $28(7-712)$ & $17(9-128)$ & 0.004 \\
\hline ALT normalization & $56(64.4 \%)$ & $20(90.9 \%)$ & 0.02 \\
\hline Bilirubin $(\mu \mathrm{mol} / \mathrm{L})$ & $15.2(4.2-212.5)$ & $19.7(8-61.4)$ & 0.27 \\
\hline Bilirubin normalization & $65(74.7 \%)$ & $17(77.3 \%)$ & 0.80 \\
\hline Albumin(g/L) & $40.4(32-48.4)$ & $35(30-38.8)$ & $<0.001$ \\
\hline Albumin normalization & $85(97.7 \%)$ & $12(54.5 \%)$ & $<0.001$ \\
\hline GGT(IU/L) & $48.0(10-227)$ & $28.5(12-93)$ & $<0.001$ \\
\hline GGT normalization & $60(69.0 \%)$ & $20(90.9 \%)$ & 0.04 \\
\hline \multicolumn{4}{|l|}{ Final follow-up } \\
\hline Months from disease onset to examination & $7.0 \pm 0.8$ & $6.9 \pm 0.7$ & 0.54 \\
\hline $\mathrm{ALT}(\mathrm{IU} / \mathrm{L})$ & $20(5-68)$ & $12(6-37)$ & 0.015 \\
\hline ALT normalization & $83(95.4 \%)$ & $22(100 \%)$ & 0.31 \\
\hline Bilirubin( $\mu \mathrm{mol} / \mathrm{L})$ & $12.1(4.2-56)$ & $13(5-22)$ & 0.47 \\
\hline Bilirubin normalization & $83(94.4 \%)$ & $22(100 \%)$ & 0.31 \\
\hline Albumin(g/L) & $43(36-48.5)$ & $39.5(34-43.0)$ & $<0.001$ \\
\hline Albumin $<35 \mathrm{~g} / \mathrm{L}$ & $0(0 \%)$ & $3(13.6 \%)$ & $<0.001$ \\
\hline GGT(IU/L) & $37(10-87)$ & $20(12-30)$ & $<0.001$ \\
\hline GGT normalization & 80 (91.9\%) & $22(100 \%)$ & 0.17 \\
\hline
\end{tabular}

NOTE. Data are expressed as mean \pm SD, median(min-max), or $n$ (\%) of patients. AHB, acute hepatitis B; ALT, alanine aminotransferase; GGT, gamma-glutmyltransferase.

\section{Discussion}

Just as it is generally accepted that pregnancy does not alter clinical recovery and mortality of AHB [25], the present study also did not find any significance difference on AHB mortality and occurrence of flulminant hepatitis between pregnant and non-pregnant patients. Clinical recovery, defined as relief of signs and symptoms, and normalization of ALT, was also similar between pregnant and non-pregnant females. However, the present study did reveal certain clinical and serological features of AHB during pregnancy.

Most of the patients in the present study were symptomatic (83.8\%), whose signs and symptoms included prodromal fever, fatigue, and loss of appetite. Fever was significantly less common ( $0 \%$ vs. $20.7 \%, P=0.02)$ in pregnant than in non-pregnant AHB patients, whereas the presence of other symptoms, such as fatigue and loss of appetite, were similar between the two groups. This finding may be partly explained by the "febrile hyporesponsiveness" phenomenon during pregnancy [26]. The febrile response is a significant contributor to the pathogenesis, clinical presentation and outcome of many illnesses and diseases [21]. During pregnancy, febrile response is suppressed by the following potential mechanisms: suppression of pro-inflammatory processes, augmentation of anti-inflammatory processes, and alterations in steroid hormones [21]. The suppressed febrile response during pregnancy can lead to a compromised ability to fight infection while it could be beneficial to the mother and the fetus. Whether the altered immunity 
Table 4 HBV serological and virological data in pregnant and non-pregnant AHB patients at admission, discharge and final follow-up

\begin{tabular}{|c|c|c|c|}
\hline Variables & Non-pregnant AHB patients $\mathrm{N}=87$ & Pregnant AHB patients $\mathrm{N}=\mathbf{2 2}$ & $P$ \\
\hline \multicolumn{4}{|l|}{ At admission } \\
\hline Days from disease onset to examination & $11.8 \pm 7.3$ & $11.3 \pm 4.1$ & 0.70 \\
\hline HBsAg positive & $6(93.1 \%)$ & $22(100 \%)$ & 0.21 \\
\hline $\mathrm{HBsAg}>250 \mathrm{IU} / \mathrm{mL}$ & $45(51.7 \%)$ & $17(77.3 \%)$ & 0.03 \\
\hline HBsAg seroconversion & $3(3.44 \%)$ & $0(0 \%)$ & 0.38 \\
\hline HBeAg positive & $52(59.8 \%)$ & $19(86.4 \%)$ & 0.02 \\
\hline HBeAg seroconversion & $33(37.9 \%)$ & $2(9.1 \%)$ & 0.01 \\
\hline HBV DNA ( $\log _{10}$ copies/mL) & $3.49(3.0-7.14)$ & $3.49(3.0-4.93)$ & 0.69 \\
\hline HBV DNA >1000 copies/mL & $55(63.2 \%)$ & $17(77.3 \%)$ & 0.21 \\
\hline \multicolumn{4}{|l|}{ At discharge } \\
\hline Days from disease onset to examination & $38.6 \pm 11.9$ & $34.2 \pm 7.1$ & 0.11 \\
\hline HBsAg positive & $54(62.1 \%)$ & $19(86.4 \%)$ & 0.03 \\
\hline $\mathrm{HBsAg}>250 \mathrm{IU} / \mathrm{mL}$ & $19(21.8 \%)$ & $9(40.9 \%)$ & 0.07 \\
\hline HBsAg seroconversion & $11(12.6 \%)$ & $0(0 \%)$ & 0.08 \\
\hline HBeAg positive & $8(9.2 \%)$ & $3(13.6 \%)$ & 0.54 \\
\hline HBeAg seroconversion & $72(82.8 \%)$ & $15(68.2 \%)$ & 0.13 \\
\hline HBV DNA >1000 copies/mL & $11(12.6 \%)$ & $1(4.5 \%)$ & 0.28 \\
\hline \multicolumn{4}{|l|}{ Final follow-up } \\
\hline Months from disease onset to examination & $7.0 \pm 0.8(5.2-8.3)$ & $6.9 \pm 0.7(5.8-8.2)$ & 0.54 \\
\hline HBsAg positive & $4(4.6 \%)$ & $4(18.2 \%)$ & 0.03 \\
\hline $\mathrm{HBsAg}>250 \mathrm{IU} / \mathrm{mL}$ & $1(1.1 \%)$ & $1(4.5 \%)$ & 0.29 \\
\hline HBsAg seroconversion & $59(67.8 \%)$ & $9(40.9 \%)$ & 0.02 \\
\hline HBeAg positive & $1(1.1 \%)$ & $1(4.5 \%)$ & 0.29 \\
\hline HBeAg seroconversion & $80(91.9 \%)$ & $19(86.3 \%)$ & 0.42 \\
\hline HBV DNA > 1000 copies/mL & $1(1.1 \%)$ & $1(4.5 \%)$ & 0.29 \\
\hline
\end{tabular}

NOTE. Data are expressed as mean \pm SD,median (min-max), or $n$ (\%) of patients; HBV, hepatitis B virus; AHB, acute hepatitis B; HBsAg,hepatitis B surface antigen; HBeAg, hepatitis e antigen.

during pregnancy affects HBV DNA replication and eradication is still inconclusive.

Several studies investigated the effect of pregnancy on serum HBV DNA levels of pregnant women with chronic HBV infection [27-29]. The study by Soderstrom et al. observed increased serum HBV DNA levels in late pregnancy or early post-partum [28]. But, Nguyen et al. reported that the levels of HBV DNA and ALT during pregnancy were highly variable [27]. Little information is available regarding the virological and serological changes during acute HBV infection in pregnant patients.

In the present study, the median HBV DNA levels and HBV DNA undetectable rate were similar between pregnant and non-pregnant patients. HBV DNA and ALT levels were highly variable in both groups.

We noted significant lower ALT levels in pregnant women. A study on acute liver failure during pregnancy by Bhatia et al. also observed significantly lower ALT levels in pregnant women than in men and non-pregnant women
[30]. Elevated serum ALT levels or symptoms reflect the T-cell-mediated HBV-specific immune response [10]. The mild symptoms and relatively low ALT levels in pregnant AHB patients indicate that HBV specific immunity in pregnancy may differ from those in the general population.

Interestingly, we noted a significantly higher $\mathrm{HBsAg}$ levels and lower HBsAg severconversion rate in pregnant patients than in non-pregnant patients. At admission and discharge, the percent of $\mathrm{HBsAg}>250 \mathrm{IU} / \mathrm{mL}$ in pregnant patients was higher than that in non-pregnant patients. Moreover, at final follow-up, about 7 months from disease onset, $18.2 \%$ of the pregnant patients were still $\mathrm{HBsAg}$ positive, a chronic HBsAg carrier state, whereas only 4.6\% of the non-pregnant patients were HBsAg positive. Also, at final follow-up, the HBsAg seroconversion rate was significantly lower in pregnant than in non-pregnant patients ( $40.9 \%$ vs. $67.8 \%, P=0.02$ ). HBsAg levels reflect the host immune control state and cccDNA levels in hepatocytes [31,32]. T-cells are markedly reduced during early 


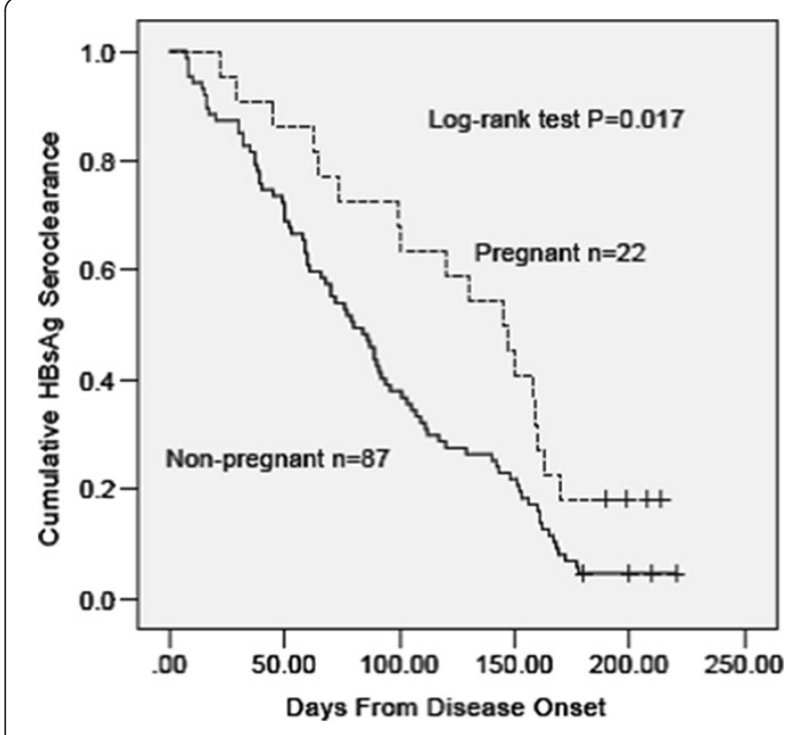

Figure 1 Changes of the $\mathrm{HBsAg}$ status after disease onset. Cumulative rates of $\mathrm{HBsAg}$ seroclearance, analyzed with the Kaplan-Meier test.

pregnancy up to the 20th week of gestation to reduce the level of immunity [15]. Increased hormone levels during pregnancy, including progesterone, estrogen and human chorionic gonadotropin, have been shown to have a clear suppressive effect on cell-mediated immunity [26]. This status may indicate that the altered immunity status may influence the eradication of HBV infected cells and the production of HBsAg antibodies. This notion is supported by the study of Mohite et al. which reported that the T cell response to HBsAg in pregnant women with AHB was absent throughout the illness, whereas that in adult males and non-pregnant females increased gradually after AHB onset [16].

We also noted a significantly more frequent and severe jaundice in pregnant women. At admission, hyperbilirubinemia was seen in all pregnant patients, and the total bilirubin level was significantly higher in pregnant than in non-pregnant patients. In acute hepatitis, serum total bilirubin level usually correlates positively with severity of liver injury [33]. However, we observed an inconsistence of total bilirubin level with peak ALT levels, a sensitive indicator of liver injury, in pregnant AHB patients. This indicate hyperbilirubinemia in pregnant AHB patients might be caused not only by intrahepatic inflammation, but possibly also by other factors influencing bilirubin clearance. Serum albumin and UDP-glucuronosyltransferase(UGP) are involved in bilirubin metabolism [34,35]. Significant lower serum albumin level, a protein that transports bilirubin, were observed in our and other studies [34,36]. An animal study revealed decreased expression of UGP1A1 during pregnancy in rat liver [37]. Recent genome-wide association studies indicated the UGP1A1 were important genes in controlling serum bilirubin [35]. These results might partially explained the inconsistence between bilirubin concentration and ALT level in pregnant AHB patients.

The serum GGT levels were also significantly lower in pregnant patients. The serum GGT activity are lower in normal pregnant women than in non-pregnant women [36]. Hepatic synthesis of GGT could be inhibited by hormone secretion during pregnancy [36].

The strong point of the present study is the use of controls matched in age, sex, alcohol consumption, and other factors which may influence the course of $\mathrm{AHB}$, with pregnant patients. Days from disease onset were also comparable between the two groups. To our knowledge, this is the first study that investigated the course of AHB during pregnancy with well matched controls.

There is a concern that 7 month follow up is too short. However, according to current acute hepatitis B investigative guidelines, those still HBV DNA-positive or HBsAgpositive are considered confirmed chronic carriers, and should be counseled accordingly [17]. In fact, we followed the patients for at least 1 year. For the pregnant AHB patients, none of them used antiviral therapy during followup, 4 patients were still HBsAg positive after at least 12 month follow-up. However, among the 618 AHB patients, for those without pregnancy, a significant portion of those still HBV DNA positive after 6 months of infection were treated with interferon or nucleotide analogues. Also, this was a hospital-based study, most patients in this study were symptomatic and relatively severe. The clinical features and outcome of asymptomatic AHB in pregnancy is not clear. To answer these questions, a large scaled population based study is needed.

\section{Conclusion}

Although the clinical recovery of AHB differs little in pregnant and non-pregnant patients, the HBsAg loss and seroconversion is delayed and lower in pregnant patients. Pregnancy might be a possible risk of chronicity following acute HBV infection. Further clinical and basic studies are necessary to confirm the findings and to elucidate the underlying mechanisms.

\section{Abbreviations}

AHB: Acute hepatitis B; ALT: Alanine aminotransferase; anti-HBC: Antibody to hepatitis core antigen; AST: Aspartate aminotransferase; GGT: Gamma-glutmyltransferase; HBsAg: Hepatitis B surface antigen; HBV: Hepatitis B virus.

\section{Competing interests}

The authors declare that there are no competing interests.

\section{Authors' contributions}

YH: acquisition of data, technical support; CS: acquisition of data; CL: acquisition of data; SX: acquisition of data; DX: acquisition of data; LL: acquisition of data; JY: acquisition of data; WL: acquisition of data; QL: study concept and design, analysis and interpretation of data, drafting of the 
manuscript, study supervision. All authors read and approved the final manuscript.

\section{Acknowledgments}

This study was funded by the Jinan Technology Development Projects [2007095-3] and the 5th Quancheng Outstanding Medical Scholar Research Fund.Thanks to Dr. Edward C. Mignot, Shandong University, for linguistic advice.

\section{Author details}

'Department of Pharmacy, Qilu Hospital, Shandong University, Jinan, China. ${ }^{2}$ Division of Liver Disease, Jinan Infectious Disease Hospital, Shandong University, Jinan, China. ${ }^{3}$ Unit of Disease Control Genome Medicine, Institute of Medical Science, University of Tokyo, Tokyo, Japan.

Received: 3 March 2014 Accepted: 30 June 2014

Published: 3 July 2014

\section{References}

1. Liang TJ: Hepatitis B: the virus and disease. Hepatology 2009, 49(5 Suppl): S13-S21.

2. Steven MM: Pregnancy and liver disease. Gut 1981, 22(7):592-614.

3. Cossart YE: The outcome of hepatitis B virus infection in pregnancy. Postgrad Med J 1977, 53(624):610-613.

4. Nayak NC, Panda SK, Datta R, Zuckerman AJ, Guha DK, Madanagopalan N, Buckshee K: Aetiology and outcome of acute viral hepatitis in pregnancy. J Gastroenterol Hepatol 1989, 4(4):345-352.

5. Jaiswal SP, Jain AK, Naik G, Soni N, Chitnis DS: Viral hepatitis during pregnancy. Int J Gynaecol Obstet 2001, 72(2):103-108.

6. Khuroo MS, Kamili S: Aetiology, clinical course and outcome of sporadic acute viral hepatitis in pregnancy. J Viral Hepat 2003, 10(1):61-69.

7. Heijtink RA, Paulij W, Van Roosmalen M, Hellings JA, Niesters HG, Schalm SW, Osterhaus AD: Characteristics of the early phase of chronicity in acute hepatitis B infection. J Med Virol 1999, 57(4):331-336.

8. Sookoian S: Liver disease during pregnancy: acute viral hepatitis. Ann Hepatol 2006, 5(3):231-236.

9. Hyams KC: Risks of chronicity following acute hepatitis B virus infection: a review. Clin Infect Dis 1995, 20(4):992-1000.

10. Ratnam D, Visvanathan K: New concepts in the immunopathogenesis of chronic hepatitis $B$ : the importance of the innate immune response. Hepatol Int 2008, 2(1):12-18.

11. Bertoletti A, Gehring AJ: The immune response during hepatitis $B$ virus infection. J Gen Virol 2006, 87(Pt 6):1439-1449.

12. Hadler SC, Judson FN, O'Malley PM, Altman NL, Penley K, Buchbinder S, Schable CA, Coleman PJ, Ostrow DN, Francis DP: Outcome of hepatitis B virus infection in homosexual men and its relation to prior human immunodeficiency virus infection. J Infect Dis 1991, 163(3):454-459.

13. Gatanaga H, Yasuoka A, Kikuchi Y, Tachikawa N, Oka S: Influence of prior HIV-1 infection on the development of chronic hepatitis B infection. Eur J Clin Microbiol Infect Dis 2000, 19(3):237-239.

14. Fujiwara K, Yokosuka O, Kojima H, Kanda T, Saisho H, Hirasawa H, Suzuki H: Importance of adequate immunosuppressive therapy for the recovery of patients with "life-threatening" severe exacerbation of chronic hepatitis B. World J Gastroenterol 2005, 11(8):1109-1114.

15. Navaneethan U, Al Mohajer M, Shata MT: Hepatitis E and pregnancy: understanding the pathogenesis. Liver Int 2008, 28(9):1190-1199.

16. Mohite BJ, Rath S, Bal V, Kamat SA, Marathe SN, Zuckerman AJ, Kamat RS: Mechanisms of liver cell damage in acute hepatitis B. J Med Virol 1987, 22(3):199-210

17. Centers for Disease Control and Prevention: Guidelines For Viral Hepatitis Surveillance And Case Management. Atlanta, GA: Centers for Disease Control and Prevention; 2005. http://www.cdc.gov/hepatitis/PDFs/ 2005Guidlines-Surv-CaseMngmt.pdf. Accessed January 6, 2013

18. Sharif O, Krishnan PV, Thekdi AD, Gordon SC: Acute hepatitis B in an urban tertiary care hospital in the United States: a cohort evaluation. J Clin Gastroenterol 2013, 47(9):e87-e90.

19. Li Q, Li WW, Yang X, Fan WB, Yu JH, Xie SS, Liu L, Ma LX, Chen SJ, Kato N, Li Q, Li WW, Yang X, Fan WB, Yu JH, Xie SS, Liu L, Ma LX, Chen SJ, Kato N: Type 2 diabetes and hepatocellular carcinoma: A case-control study in patients with chronic hepatitis B. Int J Cancer 2012, 131(5):1197-1202.
20. Li Q, Yu CH, Yu JH, Liu L, Xie SS, Li WW, Yang X, Fan WB, Gai ZT, Chen SJ, Kato N: ABO Blood Group and the Risk of Hepatocellular Carcinoma: A Case-control Study in Patients with Chronic Hepatitis B. PLOS ONE 2012, 7(1):e29928.

21. Ogoina D: Fever, fever patterns and diseases called 'fever'-a review. J Infect Public Health 2011, 4(3):108-124.

22. O'Grady NP, Barie PS, Bartlett JG, Bleck T, Carroll K, Kalil AC, Linden P, Maki DG, Nierman D, Pasculle W, Masur H: Guidelines for evaluation of new fever in critically ill adult patients: 2008 update from the American College of Critical Care Medicine and the Infectious Diseases Society of America. Crit Care Med 2008, 36(4):1330-1349.

23. Polson J, Lee WM: AASLD position paper: the management of acute liver failure. Hepatology 2005, 41(5):1179-1197.

24. Lok AS, McMahon BJ: Chronic hepatitis B. Hepatology 2007, 45(2):507-539.

25. Jonas MM: Hepatitis $B$ and pregnancy: an underestimated issue. Liver Int 2009, 29(Suppl 1):133-139.

26. Spencer SJ, Mouihate A, Galic MA, Pittman QJ: Central and peripheral neuroimmune responses: hyporesponsiveness during pregnancy. J Physiol 2008, 586(2):399-406.

27. Nguyen G, Garcia RT, Nguyen N, Trinh H, Keeffe EB, Nguyen MH: Clinical course of hepatitis $B$ virus infection during pregnancy. Aliment Pharmacol Ther 2009, 29(7):755-764.

28. Soderstrom A, Norkrans G, Lindh M: Hepatitis B virus DNA during pregnancy and post partum: aspects on vertical transmission. Scand J Infect Dis 2003, 35(11-12):814-819.

29. Ter Borg MJ, Leemans WF, De Man RA, Janssen HL: Exacerbation of chronic hepatitis B infection after delivery. J Viral Hepat 2008, 15(1):37-41.

30. Bhatia V, Singhal A, Panda SK, Acharya SK: A 20-year single-center experience with acute liver failure during pregnancy: is the prognosis really worse? Hepatology 2008, 48(5):1577-1585.

31. Sonneveld MJ, Zoutendijk R, Janssen HL: Hepatitis B surface antigen monitoring and management of chronic hepatitis B. J Viral Hepat 2011, 18(7):449-457.

32. Chisari FV, Ferrari C: Hepatitis B virus immunopathogenesis. Annu Rev Immunol 1995, 13:29-60.

33. Limdi JK, Hyde GM: Evaluation of abnormal liver function tests. Postgrad Med J 2003, 79(932):307-312

34. Billing BH, Black M: Bilirubin metabolism. Gut 1969, 10(4):250-254.

35. Johnson AD, Kavousi M, Smith AV, Chen MH, Dehghan A, Aspelund T, Lin JP, Van Duijn CM, Harris TB, Cupples LA, Uitterlinden AG, Launer L, Hofman A, Rivadeneira F, Stricker B, Yang Q, O'Donnell CJ, Gudnason V, Witteman JC: Genome-wide association meta-analysis for total serum bilirubin levels. Hum Mol Genet 2009, 18(14):2700-2710.

36. Bacq Y, Zarka O, Brechot JF, Mariotte N, Vol S, Tichet J, Weill J: Liver function tests in normal pregnancy: a prospective study of 103 pregnant women and 103 matched controls. Hepatology 1996, 23(5):1030-1034.

37. Luquita MG, Catania VA, Pozzi EJ, Veggi LM, Hoffman T, Pellegrino JM, Ikushiro S, Emi Y, lyanagi T, Vore M, Mottino AD: Molecular basis of perinatal changes in UDP-glucuronosyltransferase activity in maternal rat liver. J Pharmacol Exp Ther 2001, 298(1):49-56.

doi:10.1186/1471-2334-14-368

Cite this article as: Han et al:: Clinical features and outcome of acute hepatitis B in pregnancy. BMC Infectious Diseases 2014 14:368.

\section{Submit your next manuscript to BioMed Central and take full advantage of:}

- Convenient online submission

- Thorough peer review

- No space constraints or color figure charges

- Immediate publication on acceptance

- Inclusion in PubMed, CAS, Scopus and Google Scholar

- Research which is freely available for redistribution 